\title{
Comparative Effect of Water Extract of Parthenium hysterophorus, Datura alba, Phragmites australis and Oryza sativa on Weeds and Wheat
}

(Kesan Perbandingan Ektrak Air Parthenium hysterophorus, Datura alba, Phragmites australis dan Oryza sativa ke atas Rumpai dan Gandum)

\author{
RIAZ AHMAD AFRIDI* \& MUHAMMAD AZIM KHAN
}

\begin{abstract}
Laboratory and pot experiments were conducted at the Department of Weed Science, The University of Agriculture Peshawar, Pakistan during fall 2011 and repeated in 2012. Allelopathic plants were used against wheat and associated weeds. Allelopathic plants showed significant activity against three selected species - Triticum aestivum, Avena fatua and Rumex crispus. Aqueous extracts of Parthenium hysterophorus and Datura alba showed significant effect against weeds of Triticum aestivum although aqueous extract of Phragmites australis possessed moderate activity. It was noted that aqueous extract of Oryza sativa and control were comparable for all parameters studied. Aqueous extract of $\mathrm{P}$. hysterophorus and D. alba decreased seed germination, shoot length, fresh and dry biomass as compared to the rest of the treatments. The degree of toxicity of different treatments can be placed in the following order of inhibition: $\mathrm{P}$. hysterophorus $>$ D. alba $>$ P. australis $>\mathrm{O}$. sativa $\geq$ control. The present studies showed that the plants used contain water soluble allelochemicals that retard or inhibit the germination, growth and biomass of other species. These experiments suggests that $\mathrm{P}$. hysterophorus, D. alba and $\mathrm{P}$. australis extracts may have negative effect on major weeds like $\mathrm{A}$. fatua and $\mathrm{R}$. crispus. Thus there is a possibility of using these plant extracts for weed management. However, more extensive studies is required to identify the allelopathins responsible for inhibitory effects on seed germination and plant growth.
\end{abstract}

Keywords: Allelopathy; phytotoxicity; weeds; wheat

\section{ABSTRAK}

Uji kaji makmal dan periuk telah dijalankan di Jabatan Sains Rumpai, Universiti Pertanian Peshawar, Pakistan semasa 2011 dan diulang semula pada 2012. Tumbuhan alelopati telah digunakan terhadap gandum dan rumpai yang berkaitan. Tumbuhan alelopati menunjukkan aktiviti bererti terhadap tiga spesies yang terpilih - Triticum aestivum, Avena fatua dan Rumex crispus. Ekstrak berair Parthenium hysterophorus dan Datura alba menunjukkan kesan bererti terhadap rumpai Triticum aestivum walaupun ekstrak berair Phragmites australis mempunyai aktiviti sederhana. Turut diperhatikan bahawa ekstrak berair Oryza sativa dan kawalan adalah setanding untuk semua parameter yang dikaji. Ekstrak berair P. hysterophorus dan D. alba mengurangkan percambahan benih, panjang pucuk, segar dan biojisim kering berbanding rawatan lain. Tahap ketoksikan rawatan berbeza boleh diletakkan dalam order perencatan berikut: P. hysterophorus > D. alba $>$ P. australis $>$ O. sativa $\geq$ kawalan. Kajian ini menunjukkan bahawa tumbuhan yang digunakan mengandungi alelokimia larut air yang membantut atau merencat percambahan, perkembangan dan biojisim spesies lain. Uji kaji ini menunjukkan bahawa ekstrak P. hysterophorus, D. alba dan P. australis mungkin mempunyai kesan negatif ke atas rumpai utama seperti A. fatua dan R. crispus. Oleh itu terdapat kemungkinan menggunakan ekstrak tumbuhan ini untuk pengurusan rumpai. Walau bagaimanapun, kajian menyeluruh diperlukan untuk mengenal pasti alelopati yang bertanggungjawab terhadap kesan perencatan ke atas percambahan benih dan pertumbuhan tumbuhan.

Kata kunci: Aleopati; fitotoksisiti; gandum; rumpai

\section{INTRODUCTION}

Many studies have shown that various plant species possess the allelopathic potential to suppress weed species (Dadkhah 2012; Dadkhah \& Assadi 2010). Often in the literature, allelopathy is used to describe negative effects of one plant on another, however, this research utilized Rice's broader definition. The study of allelopathy has come under much scrutiny, as it is often difficult to construct experiments that conclusively prove the existence of ecologically relevant chemical interactions between organisms. It is well documented that the production of secondary metabolites in a plant tissue is determined by the plant genetic make-up in combination with its interaction with environmental conditions during its growth (Quader et al. 2001).

Allelopathic effects are largely determined by: the dose of chemicals exuded; chemical, physical and microbial components of soil that decide the fate of chemicals in the environment; replenishment of allelochemicals; and responses of neighboring species (Inderjit \& Duke 2003). 
The aqueous extracts of Cirsium arvense and Ageratum conyzoides could suppress the germination and early seedling growth of some weeds of wheat and the aqueous extract of Eucalyptus camaldulensis has the potential to suppress growth of Echinochloa crus-galli, A. fatua and Rumex acetosella (Moradshahi et al. 2003). Thus allelopathy is a new eco-friendly concept in sustainable agriculture (Yongqing 2005).

Oryza sativa extract has the potential to show negative effects on germination, morpho-physical and biochemical parameters due to presence of allelochmicals (Bhadoria 2011). P. hysterophorus plant shows different allelopathic effects. All the plants parts, including trichomes and pollen, contain toxins called sesquiterpene lactones, are lethal to human beings and animals (Khaliq et al.2012).

Phragmites australis is a noxious weed that has covered the water bodies throughout the country and created many problems. Ecologically realistic experiments was conducted to explore phytotoxicity of $P$. australis. Chlorophyll content was significantly reduced with leaf and rhizome leachates of P. australis by which inhibition occurred in photosynthetic rate of neighboring plants (Uddin et al. 2012). Datura alba is known for its antibacterial activity against burn pathogens (Gnanamani et al.2003) and antifungal activity against phytopathogens (Dabur et al. 2004). However, research regarding herbicidal activity of $D$. alba is lacking.

Avena fatua and Rumex crispus are two major weeds of wheat in Pakistan and the focus of weed management in wheat is always the control of these target weeds. In Pakistan the percentage losses in yield due to un-checked weed growth in different crops are significant. In some of the crops, the yield may be reduced by more than $50 \%$. It is estimated that in wheat, yield losses range from 20 to $40 \%$ due to weeds.

Allelochemicals are extracted from different plants and may be used as eco-friendly alternate to synthetic herbicides. These experiments were conducted to examine the effect of various allelochemicals on germination and growth of wheat and associated weeds. The objective of the experiment was to find out suitable allelopathic plants for the management of weeds in wheat crop.

Keeping in view the importance of weeds and environment, Oryza sativa L., Parthenium hysterophorus L., Phragmites australis Cav. and Datura alba L. were selected for the experimentation. These plants are easily available in fields around the area. Thus experiments were conducted to screen out their allelopathic effects on different parameters of wheat and associated weeds. These finding will minimize the extensive use of herbicides and will envisage the possibility of using allelochemicals to promote sustainable agriculture.

\section{MATERIALS AND METHODS}

Laboratory and pot experiments were conducted at Weed Research Lab, The University of Agriculture Peshawar $\left(34.0167^{\circ} \mathrm{N}, 71.5833^{\circ} \mathrm{E}, 340 \mathrm{~m}\right.$ asl), Pakistan during rabi season 2011 and were repeated in 2012.

\section{COLLECTION OF ALLELOPATHIC PLANTS FOR EXTRACTS}

Oryza sativa (cultivated rice 'Basmati') was collected from the experimental fields of Agricultural Research Institute Peshawar and Parthenium hysterophorus (congress weed), Phragmites australis (common reed) and Datura alba (jimson weed) were collected from Agricultural Research Farm, The University of Agriculture Peshawar, Pakistan. Whole plants were harvested at mature stage. These plants were harvested at the base above ground with the help of a sickle. The plants were cleaned from the dust and other particles and then were dried in oven for $72 \mathrm{~h}$ at $65^{\circ} \mathrm{C}$ and then were ground with the help of a grinder. The final ground samples were kept in paper bag for further use in the experiments during both years.

\section{PREPARATION OF WATER EXTRACTS}

After collection, the dried powder of the allelopathic plants were weighed and mixed in distilled water at $150 \mathrm{gL}^{-1}$ at room temperature for $48 \mathrm{~h}$ and finally filtered to collect the respective water extracts. The extracts were filtered through muslin cloth and finally through Whatman No. 1 filter paper. Water extracts were individually bottled and tagged for further process in the experimentation. Fresh extracts were prepared each year.

\section{EXPERIMENTAL DETAILS}

For the pot experiment, 10 seeds of each species (Triticum aestivum, Avena fatua and Rumex crispus) were planted in 45 plastic pots with $12 \mathrm{~cm}$ in height and $15 \mathrm{~cm}$ in diameter, filled with $1 \mathrm{~kg}$ of soil. These pots were replicated three times. All the plastic pots were irrigated with the help of mini sprayer as per needed. All the experimental plastic pots were discarded after 45 days. In case of laboratory experiment, 45 Petri dishes (each having $9 \mathrm{~cm}$ in diameter) were washed and dried. These Petri dishes were sterilized in autoclave at $110-120^{\circ} \mathrm{C}$ for $1 \mathrm{~h}$. Two filter papers were kept in each Petri dish and ten seeds of each test species were placed. These Petri dishes were replicated three times. All the Petri dishes were moistened with the help of pipette as per need. All the experimental Petri dishes were kept at room temperature of $2 \pm 2^{\circ} \mathrm{C}$ for 15 days.

\section{TEST SPECIES}

The test species T. aestivum (wheat), A. fatua (wild oat) and $R$. crispus (broad leaf dock) were included in the experiment. Germinated seeds were counted daily. The seeds were considered as germinated when the radicle size was $2 \mathrm{~mm}$. Moreover, there were five treatments in which one was a control. Each treatment was replicated three times in completely randomized design with a factorial arrangement (species and extract). The experiments were repeated once to confirm the findings. 


\section{ANALYSIS}

The germinated seeds in each treatment were counted and percentage were computed and recoded for each treatment. Seed having $2 \mathrm{~mm}$ radicle were considered as germinated. After germination, the shoot length was measured with a ruler in $\mathrm{cm}$ for all the germinated plants in each treatment and then means were recorded. Fresh biomass plant ${ }^{-1}$ was taken on an electric balance in gram (g) and subsequently means biomass plant ${ }^{-1}$ was calculated for each treatment. Similarly, dry biomass plant ${ }^{-1}$ was recorded from the above mentioned fresh biomass after drying the plants in an oven at $65^{\circ} \mathrm{C}$ for $48 \mathrm{~h}$. The dry biomass was taken on an electric balance in gram (g) and subsequently means were recorded for each treatment. Days to $50 \%$ germination of germinated seeds in each treatment were counted and recoded for each treatment. The data presented for each experiment is the mean of two years. After termination of the experiments and collection of data, the data for each parameter were subjected to the analysis of variance and the significant means were separated by LSD test (Steel \& Torrie 1980).

\section{RESULTS AND DISCUSSION}

\section{GERMINATION PERCENTAGE}

Analysis of variance of the data showed that different species showed different responses to the extracts and had significant effect on seed germination of the studied plants (Table 1). The data in pots and laboratory were recorded and mean values are presented. It was observed that maximum (94.67 and 94.34\%) germination was observed for T. aestivum followed by A. fatua (53.00 and 62.00\%). While minimum germination was noted for $R$. crispus (45.67 and 54.34\%). T. aestivum showed resistance to the allelopathic extracts as compared to rest of the species. In pot experiment, maximum germination (94.45\%) was observed in the control. While maximum (98.89\%) for germination amongst all the extract was noted in the control under laboratory experiment. Statistical analysis of the data for interaction of different plant extracts and tested species is shown in Table 1. P. hysterophorus was proved to be allelopathic by inhibiting the seed germination of all the tested plant species. $R$. crispus was the most sensitive as germination was less in all the extracts. Extracts of many weeds have potential to inhibit the germination of other weeds (Khan et al. 2004). Some weed extracts inhibited the seed germination of other weeds (Anjum et al. 2005). The allelopathic effects of various parts of same weed also differ for their effects on germination and initial plant growth (Aziz et al. 2008). However, various parts of weeds show different behavior in exerting their allelopathic effects on crops and weeds (Veenapani 2004). Weeds also exert allelopathic effects on crop seed germination and growth by releasing water soluble compounds (Batish et al. 2007). Parthenin leaching as root exudate plays a pivotal role in allelopathic interference with surrounding plants (Belz et al. 2007). Allelochemicals have also been reported as a germination and radicle growth inhibitor in a variety of dicot and monocot plants and it enters the soil through the decomposing leaf litter (Khan et al. 2004). Thus the presence of these weed species in agricultural fields can greatly affect the seed germination of cultivated crops, vegetables and other weeds. Autotoxicity at high expression levels decreases the germination, growth and yielding ability of a plant (Ben-Hammouda et al. 2002). Experimental examination of allelopathy can also vary with extraction approaches, techniques to isolate specific allelochemicals and the substrate used (Callaway et al. 2005). However, the incorporation of these weeds in the soil might be proved effective to inhibit the seed germination of weeds but how to avoid these allelochemicals not to affect the seed germination of the crop is a question that needs to be addressed on scientific backgrounds. The present study showed that the allelopathic plant extracts are effective against germination and growth of weeds. There is need to carry out studies to test the efficacy of these crude extracts under field conditions. Overall the extracts of P. hysterophorus, $P$. australis and D. alba were more toxic for the seed germination as compared to the rest of the extracts.

\section{DAYS TO 50\% GERMINATION}

Variance analysis and mean comparison results showed that days to $50 \%$ germination were affected by different allelopathic extracts (Table 2). The data regarding days to $50 \%$ germination for pot and laboratory experiments

TABLE 1. Effects of aqueous extract on germination percentage of Triticum aestivum, Avena fatua and Rumex crispus

\begin{tabular}{|c|c|c|c|c|c|c|c|c|}
\hline \multirow{3}{*}{ Treatment } & \multicolumn{3}{|c|}{ Lab experiment } & \multicolumn{5}{|c|}{ Pot experiment } \\
\hline & \multicolumn{3}{|c|}{ Species } & \multirow[t]{2}{*}{ Mean } & \multicolumn{3}{|c|}{ Species } & \multirow[t]{2}{*}{ Mean } \\
\hline & T. aestivum & A. fatua & R.crispus & & T. aestivum & A. fatua & R. crispus & \\
\hline O. sativa & $100.00 \mathrm{a}$ & $71.67 \mathrm{c}$ & $66.67 \mathrm{~cd}$ & $79.45 b$ & $98.33 \mathrm{ab}$ & $55.00 \mathrm{c}$ & $45.00 \mathrm{~cd}$ & $66.12 b$ \\
\hline P. hysterophorus & $81.67 \mathrm{bc}$ & $41.67 \mathrm{efg}$ & $33.33 \mathrm{fg}$ & $52.23 \mathrm{~d}$ & $95.00 \mathrm{ab}$ & $31.67 \mathrm{ef}$ & $21.67 f$ & $49.45 d$ \\
\hline P. australis & $96.67 \mathrm{ab}$ & $53.33 \mathrm{de}$ & $41.67 \mathrm{efg}$ & $63.89 \mathrm{c}$ & $91.67 \mathrm{ab}$ & $50.00 \mathrm{c}$ & $38.33 \mathrm{de}$ & $60.00 \mathrm{c}$ \\
\hline D. alba & $93.33 \mathrm{ab}$ & $46.67 \mathrm{ef}$ & $30.00 \mathrm{~g}$ & $56.67 \mathrm{~cd}$ & $88.33 b$ & $38.33 \mathrm{de}$ & $30.00 \mathrm{ef}$ & $52.23 \mathrm{~d}$ \\
\hline Control & $100.00 \mathrm{a}$ & $96.67 \mathrm{ab}$ & $100.00 \mathrm{a}$ & $98.89 \mathrm{a}$ & $100.00 \mathrm{a}$ & $90.00 \mathrm{ab}$ & $93.33 \mathrm{ab}$ & $94.45 \mathrm{a}$ \\
\hline Means & $94.34 \mathrm{a}$ & $62.00 \mathrm{~b}$ & $54.34 \mathrm{c}$ & & $94.67 \mathrm{a}$ & $53.00 \mathrm{~b}$ & $45.67 \mathrm{c}$ & \\
\hline
\end{tabular}

$\mathrm{LSD}_{0.05}$ for test species $=7.0236, \mathrm{LSD}_{0.05}$ for Extracts $=9.0674, \mathrm{LSD}_{0.05}$ for Interaction $=15.705$ (for lab)

$\mathrm{LSD}_{0.05}$ for Test species $=4.5267, \mathrm{LSD}_{0.05}$ for Extracts $=5.8440, \mathrm{LSD}_{0.05}$ for Interaction $=10.122$ (for pots) 
TABLE 2. Effects of aqueous extract on days to 50 percent germination of Triticum aestivum, Avena fatua and Rumex crispus

\begin{tabular}{|c|c|c|c|c|c|c|c|c|}
\hline \multirow{3}{*}{ Treatment } & \multicolumn{3}{|c|}{ Lab experiment } & \multicolumn{5}{|c|}{ Pot experiment } \\
\hline & \multicolumn{3}{|c|}{ Species } & \multirow[t]{2}{*}{ Mean } & \multicolumn{3}{|c|}{ Species } & \multirow[t]{2}{*}{ Mean } \\
\hline & T. aestivum & A.fatua & $R$. crispus & & T. aestivum & A.fatua & R.crispus & \\
\hline O. sativa & $4.67 \mathrm{~g}$ & $6.34 \mathrm{f}$ & $8.17 \mathrm{de}$ & $6.39 \mathrm{~d}$ & $8.17 \mathrm{~h}$ & 8.84efg & $9.34 \mathrm{cde}$ & $8.78 \mathrm{bc}$ \\
\hline P. hysterophorus & $5.17 \mathrm{~g}$ & $9.67 b$ & $10.67 \mathrm{a}$ & $8.50 \mathrm{a}$ & $9.50 \mathrm{~cd}$ & $11.00 \mathrm{a}$ & $11.00 \mathrm{a}$ & $10.84 \mathrm{a}$ \\
\hline P. australis & $5.00 \mathrm{~g}$ & $7.34 \mathrm{e}$ & $8.67 \mathrm{~cd}$ & $7.00 \mathrm{c}$ & $8.17 \mathrm{~h}$ & $9.00 \mathrm{def}$ & $9.84 b c$ & $9.00 \mathrm{~b}$ \\
\hline D. alba & $5.17 \mathrm{~g}$ & $8.67 \mathrm{~cd}$ & $9.67 \mathrm{~b}$ & $7.50 \mathrm{~b}$ & $8.34 \mathrm{gh}$ & $8.84 \mathrm{efg}$ & $10.17 b$ & $9.12 \mathrm{~b}$ \\
\hline Control & $4.67 \mathrm{~g}$ & $6.34 \mathrm{f}$ & $7.84 \mathrm{de}$ & $6.28 \mathrm{~d}$ & $8.17 \mathrm{~h}$ & $8.67 \mathrm{fgh}$ & $8.84 \mathrm{efg}$ & $8.56 \mathrm{c}$ \\
\hline Means & $4.94 \mathrm{c}$ & $7.57 \mathrm{~b}$ & $8.90 \mathrm{a}$ & & $8.47 \mathrm{c}$ & $9.37 \mathrm{~b}$ & $9.94 \mathrm{a}$ & \\
\hline
\end{tabular}

LSD for Test species $=0.3802$, LSD for Extracts $=0.4908$, LSD for Interaction $=0.8501$ (for lab)

$\operatorname{LSD}_{0.05}$ for Test species $=0.2589, \operatorname{LSD}_{0.05}^{0.05}$ for Extracts $=0.3343, \operatorname{LSD}_{0.05}$ for Interaction $=0.5790$ (for pots)

showed that the maximum mean values of the tested plants were noted for R. crispus (9.94 and 8.90) followed by A. fatua (9.37 and 7.57) while minimum days to $50 \%$ germination were noted for T. aestivum (8.47 and 4.94), respectively. $R$. crispus was proved sensitive to the plant extracts as compared to other tested species. Data regarding plant extracts in pots and laboratory for days to $50 \%$ germinations showed that the maximum mean values was observed in the P. hysterophorus (10.84 and 8.50) followed by $D$. alba (9.12 and 7.50) and P. australis $(9.00$ and 7.00) as compared to O. sativa (8.78 and 6.39\%) and the control (8.56 and 6.28), respectively. The interaction exhibited that maximum days to $50 \%$ germination was noted in the treatments of P. hysterophorus and D. alba. While minimum was found under the control and $O$. sativa treatments. P. hysterophorus, $P$. australis and $D$. alba had visible allelopathic effects by delaying the seed germination of all the tested plant species. O. sativa showed the least allelopathic effect as compared to the other treatments. The reason for early emergence of the seed may be due to the completion of pre-germination metabolic activities making the seed ready for radicle protrusion (Arif 2005). The overall results showed that different extracts have significant effects on the days to $50 \%$ germination. It seems that these extracts can be used for weed management in crops. Allelochemicals are considered as toxic plant chemicals and industrial uses are reported (Babar et al. 2009). The results are supported by the findings of Stavrianakou et al. (2004) who reported increase in germination time of crop and weed plants with the extract of different weeds. Species varied in their sensitivity to aqueous extracts of P. hysterophorus for both germination and plant growth (Regina et al. 2007) and thus it is a potential source of natural bio herbicide (Gurdeep et al. 2009). Potential of allelopathic compounds is often verified by testing their influence on seed germination and seed viability. Negative effects of allelochemicals on the seed germination, time to germinate and initial growth of Sorghum bicolor, Triticum aestivum, Helianthus annuus and Secale cereale have already reported (Inderjit \& Callaway 2003; Inderjit \& Duke 2003). These results are also in agreement with those of Babar et al. (2009), who stated that chickpea seeds soaked in root extract of Asphodelus tenuifolius took more time for germination. From the above study, negative effects on the quantitative characters was observed leading to the conclusion that the allelochemicals may be exploited for weed management. The understanding of mechanism, identification and isolation of allelochemicals may provide a basis for development of growth regulators and natural pesticides to boost up production in sustainable agriculture. However, the use of allelochemicals for weed management is passing through experimental trials to commercialize for farmer use.

\section{SHOOT LENGTH}

Analysis of variance on the data showed that various plant extracts had significant effect on the shoot length of the tested species (Table 3). Shoot length with the highest mean values were recorded for T. aestivum (32.52 and $17.60 \mathrm{~cm})$ while the lowest values were noted for $R$. crispus $(8.03$ and $3.12 \mathrm{~cm}$ ), respectively. All the plant extracts significantly reduced shoot length as compared with the control treatment. Maximum mean values of the shoot length were recorded in the control $(28.74$ and $13.86 \mathrm{~cm})$ under pot and laboratory experiments, respectively. These were followed by $O$. sativa $(25.04$ and $13.05 \mathrm{~cm})$, while minimum shoot length was noticed in P. hysterophorus (17.09 and $9.92 \mathrm{~cm}$ ) and D. alba (19.39 and $10.93 \mathrm{~cm})$. These results showed that allelopathic potential of O. sativa is less than the other species and hence should be further explored for practical use in the fields. The interaction between extracts and tested species showed that maximum shoot length was recorded for T. aestivum under the control and $O$. sativa treatments. While minimum shoot length was noted for $R$. crispus under D. alba treatment. Overall, P. hysterophorus and $D$. alba showed significant allelopathic effects by inhibiting and minimizing the shoot length of all the tested species except T. aestivum. Many of the weed species used for testing the allelopathic potential are less explored and this needs to be addressed in agro-ecosystem. These results are in agreement with the findings that water extracts of allelopathic plants generally have more pronounced effects on radicle rather than hypocotyl growth (Turk \& Tawaha 2002). This may be attributable to the fact that radicles are 
TABLE 3. Effects of aqueous extract on shoot length (cm) of Triticum aestivum, Avena fatua and Rumex crispus

\begin{tabular}{|c|c|c|c|c|c|c|c|c|}
\hline \multirow{3}{*}{ Treatment } & \multicolumn{3}{|c|}{ Lab experiment } & \multicolumn{5}{|c|}{ Pot experiment } \\
\hline & \multicolumn{3}{|c|}{ Species } & \multirow[t]{2}{*}{ Mean } & \multicolumn{3}{|c|}{ Species } & \multirow[t]{2}{*}{ Mean } \\
\hline & T. aestivum & A. fatua & R. crispus & & T. aestivum & A. fatua & R. crispus & \\
\hline O. sativa & $18.58 \mathrm{a}$ & $17.37 \mathrm{c}$ & $3.65 \mathrm{i}$ & $13.05 \mathrm{~b}$ & $33.27 b c$ & $32.97 b c$ & $8.89 \mathrm{~g}$ & $25.04 \mathrm{~b}$ \\
\hline P. hysterophorus & $16.44 d$ & $11.16 \mathrm{~g}$ & $2.17 \mathrm{j}$ & $9.92 \mathrm{e}$ & $30.96 \mathrm{~d}$ & $15.83 f$ & $4.49 \mathrm{i}$ & $17.09 \mathrm{e}$ \\
\hline P. australis & $17.64 b c$ & $15.56 \mathrm{e}$ & $3.30 \mathrm{i}$ & $12.17 \mathrm{c}$ & $32.65 \mathrm{bcd}$ & $32.17 \mathrm{~cd}$ & $6.69 \mathrm{~h}$ & $23.84 \mathrm{c}$ \\
\hline D. alba & $17.15 \mathrm{c}$ & $13.48 \mathrm{f}$ & $2.15 \mathrm{j}$ & $10.93 \mathrm{~d}$ & $31.59 \mathrm{~cd}$ & $20.86 \mathrm{e}$ & $5.69 \mathrm{hi}$ & $19.39 \mathrm{~d}$ \\
\hline Control & $18.67 \mathrm{a}$ & $18.13 \mathrm{ab}$ & $4.320 \mathrm{~h}$ & $13.86 a$ & $37.74 a$ & $34.09 \mathrm{~b}$ & $14.39 \mathrm{f}$ & $28.74 a$ \\
\hline Means & $17.60 \mathrm{a}$ & $15.23 b$ & $3.114 \mathrm{c}$ & & $32.52 \mathrm{a}$ & $27.92 b$ & $8.03 \mathrm{c}$ & \\
\hline
\end{tabular}

the first to come in contact with allelochemicals. Aqueous extracts of allelopathic grasses suppressed the germination and growth of P. hysterophorus (Anjum et al. 2005; Javaid et al. 2005). Our findings showed similarity with the results reported by Shahnaz et al. (2010) that water extract of W. somnifera and D. alba possessed some bioactive compounds which significantly inhibited the growth of root and shoot of $R$. crispus, highly competitive weed in wheat. A similar trend was also reported previously (Fujii et al. 2003). The instant results showed that presence of allelopathic weeds in the agricultural fields may pose a serious threat to the crop production as these plants will release allelochemicals to the soil environment and thus could result in failure of crop seed germination. On the other hand, these weeds provide opportunity to be used for weed management. In a similar study, Cheema and Khaliq (2000) reported that allelochemicals are effective and could be successfully used in weed management techniques. However, the presences of allelochemicals in plants depend on many factors.

\section{FRESH BIOMASS PLANT ${ }^{-1}$}

Statistical data for pots and laboratory showed that different plant extracts had significant effect on the fresh biomass of the tested species (Table 4). Means value of the tested species depicted that the highest fresh biomass was observed for T. aestivum ( 0.82 and $0.09 \mathrm{~g}$ ) followed by
A. fatua (0.66 and $0.05 \mathrm{~g}$ ) while the lowest fresh biomass was noted for $R$. crispus ( 0.54 and $0.02 \mathrm{~g}$ ). The maximum mean values of fresh biomass was recorded in the control treatments $(0.94$ and $0.07 \mathrm{~g})$ whereas minimum fresh biomass was exhibited by P. hysterophorus ( 0.4 and 0.04 $\mathrm{g})$, respectively. The interaction amongst various plant extracts and tested species was also observed. So it was noted that maximum fresh biomass was achieved in the control treatments as well as by the treatment of $O$. sativa. While the minimum fresh biomass was recorded under $P$. hysterophorus treatments followed by $D$. alba. The presence of allelochemicals has been explored and many scientists are of the view that allelopathins are present in various parts of the plants and can greatly affect the receiver plants in many ways. However, allelochemicals are synthesized in plants as secondary metabolites and located in certain specialized organs of donor plants (Kobayashi 2004). The most abundant inhibitors in $P$. hysterophorus was the sesquiterpene lactone parthenin which is sequestered at high level in capitate sessile trichomes present on leaves, stems and the achene complex (Reinhardt et al. 2004). These results are also in agreement with Shahnaz et al. (2010) who stated that water extract of W. somnifera and D. alba possessed some bioactive compounds which significantly inhibited the growth of root and shoot, plumule and radical extension. Decreasing biomass of weeds due to application of allelochemicals is an indicator of success of such studies. Although herbicides

TABLE 4. Effects of aqueous extract on fresh biomass (g) plant ${ }^{-1}$ of Triticum aestivum, Avena fatua and Rumex crispus

\begin{tabular}{|c|c|c|c|c|c|c|c|c|}
\hline \multirow{3}{*}{ Treatment } & \multirow{2}{*}{\multicolumn{3}{|c|}{$\begin{array}{l}\text { Lab experiment } \\
\text { Species }\end{array}$}} & \multicolumn{5}{|c|}{ Pot experiment } \\
\hline & & & & \multirow[t]{2}{*}{ Mean } & \multicolumn{3}{|c|}{ Species } & \multirow[t]{2}{*}{ Mean } \\
\hline & T. aestivum & A. fatua & R. crispus & & T. aestivum & A.fatua & R.crispus & \\
\hline O. sativa & $0.10 \mathrm{ab}$ & $0.06 \mathrm{~d}$ & $0.02 \mathrm{~g}$ & $0.06 \mathrm{~b}$ & $0.97 \mathrm{a}$ & $0.90 \mathrm{ab}$ & $0.77 \mathrm{~cd}$ & $0.881 \mathrm{~b}$ \\
\hline P. hysterophorus & $0.09 \mathrm{~b}$ & $0.01 \mathrm{~h}$ & $0.01 \mathrm{~h}$ & $0.04 d$ & $0.62 \mathrm{e}$ & $0.36 \mathrm{~g}$ & $0.25 \mathrm{~h}$ & $0.40 \mathrm{e}$ \\
\hline P. australis & $0.09 \mathrm{ab}$ & $0.05 \mathrm{e}$ & $0.01 \mathrm{~h}$ & $0.06 \mathrm{~b}$ & $0.77 \mathrm{~cd}$ & $0.58 \mathrm{e}$ & $0.47 \mathrm{f}$ & $0.59 \mathrm{c}$ \\
\hline D. alba & $0.09 \mathrm{ab}$ & $0.04 \mathrm{f}$ & $0.01 \mathrm{~h}$ & $0.05 \mathrm{c}$ & $0.74 \mathrm{~d}$ & $0.460 \mathrm{f}$ & $0.38 \mathrm{fg}$ & $0.53 \mathrm{~d}$ \\
\hline Control & $0.10 \mathrm{a}$ & $0.07 \mathrm{c}$ & $0.01 \mathrm{~g}$ & $0.07 \mathrm{a}$ & $0.99 a$ & $0.98 \mathrm{a}$ & $0.853 \mathrm{bc}$ & $0.94 \mathrm{a}$ \\
\hline Means & $0.09 \mathrm{a}$ & $0.05 b$ & $0.02 \mathrm{c}$ & & $0.82 \mathrm{a}$ & $0.66 b$ & $0.54 \mathrm{c}$ & \\
\hline
\end{tabular}

$\mathrm{LSD}_{0.05}$ for Test species $=2.798, \mathrm{LSD}_{005}$ for Extracts $=3.612, \mathrm{LSD}_{0.05}$ for Interaction $=6.256$ (for lab)

$\operatorname{LSD}_{0.05}$ for Test species $=0.0448, \operatorname{LSD}_{0.05}$ for Extracts $=0.0579, \mathrm{LSD}_{0.05}$ for Interaction $=0.1003$ (for pots) 
TABLE 5. Effects of aqueous extract on dry biomass (g) plant ${ }^{-1}$ of Triticum aestivum, Avena fatua and Rumex crispus

\begin{tabular}{|c|c|c|c|c|c|c|c|c|}
\hline \multirow{3}{*}{ Treatment } & \multicolumn{3}{|c|}{ Lab experiment } & \multirow{3}{*}{ Mean } & \multicolumn{3}{|c|}{ Pot experiment } & \multirow{3}{*}{ Mean } \\
\hline & \multicolumn{3}{|c|}{ Species } & & \multicolumn{3}{|c|}{ Species } & \\
\hline & T. aestivum & A.fatua & R. crispus & & T. aestivum & A. fatua & R. crispus & \\
\hline O. sativa & $0.03 \mathrm{a}$ & $0.02 \mathrm{~d}$ & $0.02 \mathrm{e}$ & $0.02 \mathrm{a}$ & $0.42 \mathrm{abc}$ & $0.47 \mathrm{ab}$ & $0.12 \mathrm{efg}$ & $0.33 \mathrm{ab}$ \\
\hline P. hysterophorus & $0.02 \mathrm{c}$ & $0.01 \mathrm{i}$ & $0.01 \mathrm{i}$ & $0.01 \mathrm{~b}$ & $0.39 b c$ & $0.17 \mathrm{de}$ & $0.03 \mathrm{~h}$ & $0.19 \mathrm{c}$ \\
\hline P. australis & $0.03 \mathrm{~b}$ & $0.01 \mathrm{ef}$ & $0.01 \mathrm{fg}$ & $0.02 \mathrm{a}$ & $0.42 \mathrm{abc}$ & $0.39 \mathrm{c}$ & 0.09fgh & $0.29 b$ \\
\hline D. alba & $0.03 \mathrm{~b}$ & $0.01 \mathrm{gh}$ & $0.01 \mathrm{~h}$ & $0.02 \mathrm{a}$ & $0.40 \mathrm{bc}$ & $0.23 \mathrm{~d}$ & $0.06 \mathrm{gh}$ & $0.23 \mathrm{c}$ \\
\hline Control & $0.03 \mathrm{a}$ & $0.02 \mathrm{c}$ & $0.02 \mathrm{~d}$ & $0.02 \mathrm{a}$ & $0.48 \mathrm{a}$ & $0.45 a b c$ & $0.14 \mathrm{ef}$ & $0.36 \mathrm{a}$ \\
\hline Means & $0.03 \mathrm{a}$ & $0.01 \mathrm{~b}$ & $0.01 \mathrm{~b}$ & & $0.42 \mathrm{a}$ & $0.34 \mathrm{~b}$ & $0.083 \mathrm{c}$ & \\
\hline
\end{tabular}

$\mathrm{LSD}_{005}$ for Test species $=9.33, \mathrm{LSD}_{005}$ for Extracts $=1.204, \mathrm{LSD}_{005}$ for Interaction $=2.086$ (for lab)

$\mathrm{LSD}_{0.05}$ for Test species $=0.0299, \mathrm{LSD}_{0.05}$ for Extracts $=0.0386, \mathrm{LSD}_{0.05}$ for Interaction $=0.0669$ (for pots)

are cheaper and effective as compared to allelochemicals, but still it seems that allelopathins could be successfully used for weed control in developing countries by small farmers. The present findings agree with those of Meihua et al. (2006) who observed that allelochemicals reduced the chlorophyll content in plants. Further studies are suggested to encompass active ingredient of allelochemicals to understand the different behaviors and plant responses to their application.

\section{DRY BIOMASS PLANT ${ }^{-1}$}

The tested species showed different responses to plant extracts and appreciably affected the dry biomass of the tested plants (Table 5). Mean values of the tested species showed that the highest dry biomass was noted for $T$. aestivum $(0.42$ and $0.03 \mathrm{~g})$, followed by A.fatua ( 0.34 and $0.01 \mathrm{~g})$. Whereas the lowest dry biomass was noticed for $R$. crispus $(0.083$ and $0.01 \mathrm{~g})$. The highest mean values for dry biomass were observed in the control ( 0.36 and $0.02 \mathrm{~g}$ ) while minimum dry biomass was recorded in the P. hysterophorus $(0.19$ and $0.01 \mathrm{~g})$. The interaction of different extracts and tested species showed that the highest dry biomass was noticed under control treatment while the lowest dry biomass was recorded in the treatment of $P$. hysterophorus as well as under the treatment of $D$. alba. Thus T. aestivum was the most tolerant species probably due to inherent genetic makeup. The extract of $O$. sativa and control showed comparable effects. Whereas P. hysterophorus, $D$. alba and $P$. australis showed allelopathetic effects by retarding or inhibiting seed germination and growth and fresh/dry biomass of tested species. Stronger effects of allelochemicals of $P$. hysterophorus on growth are severe than on seed germination as reported by Batish et al. (2002). The release of allelochemicals by P. hysterophorus and $D$. alba through aqueous extracts under laboratory conditions proved to be sufficient to provide significant phytotoxicity and the relative role of allelopathic plants. Thus, current findings provide evidence that the release of allelochemicals has the capacity to play a leading role. If this laboratory potential may play a substantial role in the interference of $P$. hysterophorus with surrounding plant species in nature, it will be governed by several influencing factors. These results are also in agreement with Regina et al. (2007) and Shahnaz et al. (2010), who stated that the observed variability of allelochemical content in $P$. hysterophorus and D. alba extracts suggests a major contribution restricted to situations where allelochemicals dominating the spectrum of inhibitors released from these plants. Ahn et al. (2005) stated that the rate of release of allelochemicals from allelopathic plants is proportional to the total amount present within the said plants and one could assume that allelochemicals will be the determining factor for allelopathy only if high levels are accumulated in the plants. The findings demonstrated that allelochemicals are amongst those inhibitors that under laboratory conditions causing delay in germination and reducing plant growth and biomass. However, the proper dose, time of application and method of application are important factors that can significantly contribute to use allelochemicals for weed management.

\section{ACKNOWLEDGEMENTS}

This study is a part of $\mathrm{PhD}$ dissertation and will be submitted to The University of Agriculture Peshawar, Pakistan. Authors are highly thankful to ALP/PARC for partial financial assistance to carry out this study under Project No. CS086.

\section{REFERENCES}

Aziz, A., Tanveer,A., Ali, M., Yasin, M., Babar, B.H. \& Nadeem, M.A. 2008. Allelopathic effect of cleavers (Galium aparine) on germination and early growth of wheat (Triticum aestivum). Allelopathy J. 22: 25-34.

Ahn, J.K., Hahn, S.J., Kim, J.T., Khan, T.D. \& Chung, I.M. 2005. Evaluation of allelopathic potential among rice (Oryza sativa L.) germplasm for control of Echinochloa crusgalli P. Beauv in the field. J. Crop Prot. 24(5): 413-419.

Anjum, T., Bajwa, R. \& Javaid, A. 2005. Biological control of parthenium I: Effect of Imperata cylindrica on distribution, germination and seedling growth of Parthenium hysterophorus L. Int. J. Agric. Biol. 7(3): 448-450.

Arif, M. 2005. Seed Priming Improves Emergence, Yield and Storability of Soybean. PhD thesis in Agronomy. NWFP Agricultural University Peshawar, Pakistan (unpublished).

Babar, B.H., Tanveer, A., Tahir, M.A., Aziz Ahmad, A.U.H., Nadeem, M.A. \& Javaid, M.M. 2009. Allelopathic potential of wild onion (Asphodelus tenuifolius) on the germination 
and seedling growth of chickpea (Cicer arietinum). Weed Biol. Manag. 9: 146-151.

Batish, D.R., Lavanya, K., Singh, H.P. \& Kohli, R.K. 2007. Phenolic allelochemicals released by Chenopodium murale affect the growth, nodulation and macromolecule content in chickpea and pea. Plant Growth Regul. 51: 119-128.

Batish, D.R., Singh, H.P., Kohli, R.K., Saxena, D.B. \& Kaur, S. 2002. Allelopathic effects of parthenin against two weedy species, Avena fatua and Bidens pilosa. Environ. Exp. Bot. 47: $149-155$

Ben-Hammouda, M., Ghorbal, H., Kremer, R.J. \& Queslatt, O. 2002. Autotoxicity of barley. J. Plant Nutr. 25: 1155-1161.

Belz, R.G., Reinhardt, C.F., Foxcroft, L.C. \& Hurle, K. 2007. Residue allelopathy in Parthenium hysterophorus L. does parthenin play a leading role? Crop Prot. 26: 237-245.

Bhadoria, P.B.S. 2011. Allelopathy: A natural way towards weed management. Am. J. Exp. Agric. 1(1): 7-20.

Callaway, R.M., Ridenour, W.M., Laboski, T., Weir, T. \& Vivanco, J.M. 2005. Natural selection for resist to the allelopathic effects of invasive plants. J. Ecol. 93: 576-583.

Cheema, Z.A. \& Khaliq, A. 2000. Use of sorghum allelopathic properties to control weeds in irrigated wheat in a semi-arid region of Punjab. Agric. Ecosyst. Environ. 79: 105-112.

Dabur, R., Ali, M., Singh, H., Gupta, J. \& Sharma, G.L. 2004 . A novel antifungal pyrrole derivative from Datura metel leaves. Pharmazie 59: 568-570.

Dadkhah, A. 2012. Phytotoxic effects of aqueous extracts of Eucalyptus, sunflower and sugar beet on seed germination, growth and photosynthesis of Amaranthis retroflexus. Allelopathy J. 29: 287-296.

Dadkhah, A. \& Assadi, M. 2010. Allelopathic effects of Eucalyptus camaldulensis on germination and growth seedlings of Acroptilon repens, Plantago lanceolata and Portulaca oleracea research. J. Biol. Sci. 5: 430-434.

Fujii, Y., Parvez, S.S., Parvez, M.M., Ohmae, Y. \& Iida, O. 2003. Screening of 239 medicinal plant species for allelopathic activity using sandwich method. Weed Biol. Manag. 3: 233-241.

Gnanamani, A.K., Priya, S., Radhakrishnan, N. \& Babu, M. 2003. Antibacterial activity of two plant extracts on eight burn pathogens. J. Ethnophormocol. 86(1): 59-61.

Gurdeep, B., Amutha, S., Kumar, Thimmaraju, R., Emily, A., Thomas, E.H. \& Harsh, P.B. 2009. Native plant and microbial contributions to a negative plant-plant interaction. Plant Physiol. 151: 2145-2151.

Inderjit \& Callaway, R.M. 2003. Experimental designs for the study of allelopathy. Plant Soil 256: 1-11.

Inderjit \& Duke, S.O. 2003. Ecophysiological aspects of allelopathy. Planta 217: 529-539.

Javaid, A., Anjum, T. \& Bajwa, R. 2005. Biological control of Parthenium II: Allelopathic effect of Desmostachya bipinnata on distribution and early seedling growth of Parthenium hysterophorus L. Int. J. Biol. \& Biotech. 2(2): 459-463.

Khan, M.A., Marwat, K.B. \& Hassan, G. 2004. Allelopathic potential of some multipurpose tree species (MPTS) on wheat and some of its associated weeds. Int.J. Biol.Biotch. 1(3): 275-278.
Khaliq, A., Matloob, A., Mahmood, S., Abbas, R.N. \& Bismillah, M. 2012. Seeding density and herbicide tank mixtures furnish better weed control and improve growth, yield and quality of direct seeded fine rice. Int. J. Agric. \& Biol. 14(4): 499-508.

Kobayashi, K. 2004. Factors affecting phytotoxic activity of allelochemicals in soil. Weed Biol. Manag. 4: 1-7.

Meihua, M., Xiao, O., Zhang, Y. \& Nie, C. 2006. Allelopathy of aqueous leachates of Lactarius hatsudake on several crops and barnyard grass (Echinochloa cruss-galli L.). Proc. 4th World Cong. on Allelopath, Wagga Australia.

Moradshahi, A., Ghadiri, H. \& Ebrahimikia, F. 2003. Allelopathic effects of crude volatile oil and aqueous extracts of Eucalyptus camaldulensis Dehnh., leaves on crops and weeds. Allelopathy J. 12(2): 189-195.

Quader, M., Daggard, G., Barrow, R., Walker, S. \& Sutherland, M.W. 2001. Allelopathy, DIMBOA production and genetic variability in accessions of Triticum spletoides. J. Chem. Ecol. 27: 742-760.

Regina, G.B., Reinhardtb, C.F., Foxcroftc, L.C. \& Hurlea, K. 2007. Residue allelopathy in Parthenium hysterophorus L.Does parthenin play a leading role? Crop Prot. 26: 237-245.

Reinhardt, C., Kraus, S., Walker, F., Foxcroft, L., Robbertse, P. \& Hurle, K. 2004. The allelochemical parthenin is sequestered at high level in Capitate-sessile trichomes on the leaf surface of Parthenium hysterophours. J. Plant Dis. Prot. 19: 253-261.

Shahnaz, D., Sadia, K. \& Marium, T. 2010. Comparative effect of plant extract of Datura alba and Cynodon dactylon, alone or in combination with microbial antagonists for the control of root rot disease of cowpea and okra. Pak. J. Bot. 42(2): 1273-1279.

Stavrianakou, S., Liakoura, V., Levizou, E., Karageorgou, P., Delis, C., Liakopoulos, G., Karabourniotis, G., Manetas, G. \& Manetas, Y. 2004. Allelopathic effect of water-soluble leaf epicuticular material from Dittrichia viscosa on seed germination of crops and weed. Allelopathy J. 14: 35-41.

Turk, M.A. \& Tawaha, A.M. 2002. Inhibitory effects of aqueous extracts of barley on germination and growth of lentil. Pak. J. Agron. 1: 28-30.

Uddin, M.K., Juraimi, A.S., Ismail, M.R., Hossain, M.A., Rahim, M.A. \& Radziah, O. 2012. Physiological and growth response of tropical turfgrass to salinity stress. The Scient. World J. 10: 1100 .

Veenapani, D. 2004. Inhibition in seed germination of Oryza sativa by two weed species. Flora Fauna 10: 11-12.

Yongqing, M.A. 2005. Allelopathic studies of common wheat (Triticum aestivum L.). Weed Biol. Manag. 5: 93-104.

Department of Weed Science

The University of Agriculture Peshawar

25130 Pakistan

*Corresponding author; email: ahmadzaipk@yahoo.com

Received: 24 October 2014

Accepted: 12 January 2015 